\title{
A RENAISSANCE DEPICTION OF A TORNADO
}

\author{
by Klaus P. Hoinka and Manuel de Castro
}

\author{
A Flemish tapestry demonstrates how weather in sixteenth-century art can be \\ of testimonial, decorative, or emblematic character.
}

D uring the Renaissance (1400-1600) meteorological phenomena attracted the interest of diletantes and artists. Interest in the weather expressed itself in the form of individual weather notes (see Hellman 1901), the first serious attempts to provide some rules for predicting the weather (Hellmann 1915, 1924a), and the well-established astrometeorological approaches to forecasting the weather. The Renaissance period saw increasing attention toward meteorological observations, in comparison to the preceeding centuries where meteorology was dominated by Aristotle's "Meteorologica” (3400 в.с.). The invention of quantitative measuring devices, such as the thermometer (in 1607) and the barometer (1643), was yet to come.

The fresh stimulus for weather observations came at the end of the fifteenth century from the great

AFFILIATIONS: HoINKA-Institut für Physik der Atmosphäre, DLR, Oberpfaffenhofen, Germany; DE CASTRO-Departamento Ciencias Ambientales, Universidad Castilla-La Mancha, Toledo, Spain

CORRESPONDING AUTHOR: Klaus P. Hoinka, Institut für Physik der Atmosphäre, DLR, Oberpfaffenhofen, Postfach III6, D-82230 Wessling, Germany

E-mail:klaus.hoinka@dlr.de

DOI:10.1175/BAMS-86-4-543

In final form 14 January 2005

(C)2005 American Meteorological Society discoveries of new lands and seas, which considerably enlarged and widened old ideas and conceptions. Atmospheric phenomena never seen before were identified by Western explorers, and climates that were very different from those at home became known (Hellmann 1908). Among these new meteorological phenomena, tornadoes and waterspouts provoked considerable interest due to their damaging effects, as well as their beauty. For centuries, the concept of tornadoes was indistinguishable from people's notions of other windstorms. The word "tornado" had an archaic meaning concerning variable, gusty winds and rain, and, perhaps, thunderstorms near the equator.

The Oxford English Dictionary (1989) defines a tornado in the following way: "In the 16th century navigators called a tornado (or ternado) a violent thunderstorm of the tropical Atlantic, with torrential rain, and often with sudden and violent gusts of wind ... later on a tornado was defined as a violent storm (now without thunder), affecting a limited area, in which the wind is constantly changing its direction or rotating." The definition, including the thunderstorm, was used for the first time in 1556, whereas the thunder-free definition was applied later beginning in 1625. The first edition of Encyclopaedia Brittanica, published in 1771, defined a tornado as "a sudden and vehement gust of wind from all points of the compass, frequent on the coast of Guinea." The term "tornado" originates from various terms, such as 
"ternado," "tornatho," "trovados," and others. It was not until the 1840s that the Spanish word "tornado" was narrowed in meaning to designate a local rotary storm (Ludlam 1970). Fleming (1990) pointed out that there was still an argument about terminology such as tornado, whirlwind, and hurricane as late as about 1840. For a detailed discussion of the word's origin see Snow and Wyatt (1997) and Kentworthy (2000).

The Roman encyclopedist most widely read in the Renaissance was Pliny the $\operatorname{Elder}^{1}$ (23-79 A.D.) who described in his "Historia naturalis" (70 A.D.) the menace of whirlwinds to sailors, and also mentioned the waterspout, "that cloud which draweth water to it, as it were into a long pipe" (Heninger 1960). Although an increased number of observations of tornadoes were recorded during the sixteenth century, reports focusing on scientific aspects are rare during this time (Wegener 1917). Ludlum (1963) pointed out that in his diary Columbus described a tornado that turned into a waterspout during his second voyage in 1495 (see also Brooks 1941). Also, Machiavelli (1469-1527) described a tornado crossing Tuscany (Machiavelli 1532), and the Portuguese navigator and poet Luiz de Camões (1524-80) documented poetically a waterspout that was probably observed on the western coast of Africa (Hellmann 1924b). We must not forget Shakespeare (1564-1616), who referenced a waterspout in his play "Troilus and Cressida," "the dreadful spout, which shipmen do the hurricane call, constringent in mass by the almighty sun." Originally, the tornado-like phenomenon is differently termed in historic texts, for example, Machiavelli used the word "storm." A variety of terms denoting tornadic activity is also evident in the description of early American tornadoes (Ludlam 1970). Thus, following its pictorial and verbal description given in historic texts describing a tornado, it is reasonable to use the present-day meaning of tornado. References to historic reports on tornadoes may be found in Fleming and Goodman (1994).

Dilettantes as well as artists were attracted by this weather phenomenon, and during the Renaissance period the first depictions of them appear. Wegener (1917) identified the illustration of a tornado of 1587 as being the first tornado drawing ever done in Germany, and he assumed that it was probably the first worldwide (Fig. 1). In the present paper an earlier image of a tornado, and depictions of heavy rain and of a sandstorm are presented and discussed; these appear in a series of tapestries designed and woven about

${ }^{1}$ No less than 128 editions of his "Historia naturalis" had been published by the end of the fifteenth century (Heninger 1960).
40 years earlier. The tornado and the rain appear on the first tapestry and the sandstorm on the fourth in the series of 12 tapestries called the "Conquest of Tunis," which were made for the emperor Charles V (1500-58). In 1535 he undertook a crusade to Tunis in order to diminish the Ottoman emperor's power in the western Mediterranean region. In order to ensure that the expedition would not be forgotten, Charles $\mathrm{V}$ brought along poets, musicians, mathematicians, astrologers, and the Flemish painter Jan Cornelisz Vermeyen (1500-59).

Vermeyen painted sketches depicting important scenes of the crusade to be used as prototypes for the tapestry series "Conquest of Tunis," later woven in Brussels by the carpet manufacturer Willem de Pannemaker. These tapestries present a detailed narrative of the expedition to Tunis-the pacification of Cape Carthago, the struggle of Golesta, the capture of Tunis, and the aftermath. The largest part of each tapestry contains the representation of these scenes. The rest (about 5\%) show skies that are clear, partly cloudy, or overcast, but without any significant structure and depicted in a purely decorative manner.

To the authors' knowledge the meteorological features shown in this tapestry are neither discussed nor mentioned in the related art literature (e.g., Horn 1989; Seipel 2000). The reason for this might be that art historians favor either formal subjects or are critical of the circumstances of the creation of the work, which likewise would cause them to gloss over what is otherwise a very good picture of a tornado. Other historians err in reading paintings strictly for information, viewing them as transparent representations. On the other hand, meteorologists tend to notice merely the depiction of meteorological elements, but neglect the symbolic character of the painted meteorological features. Gedzelman (1989), a representative example of the latter view, gives a comprehensive history of cloud painting prior to the first classification schemes of Luke Howard of 1803. Clearly, artists tend to look at the sky differently than meteorologists, who sometimes emphasize features that artists have not been trained to notice. Therefore, we discuss in the present paper significant weather elements as found in the series of tapestries and try to put their appearance into historical context. This includes a brief discussion of how weather features and landscapes are depicted in pieces of Renaissance art.

\section{CHARLES V'S CRUSADE TO TUNIS AND THE “CONQUEST OF TUNIS" TAPES - TRIES SERIES. The sixteenth century is character-}


ized by a strong contrast between Christendom and Islam, with a long boundary running from the Balkans through the Mediterranean region. The Ottoman emperor was an ambitious ruler over many rich lands and was a determined warrior. There were a number of confrontations between both powers, including one in 1535. A corsair named Barbarossa was commissioned as admiral of the sea by the Ottoman emperor and was active in disturbing the growing flow of trade goods and merchants in the western Mediterranean Sea. This pirate had become a serious menace by 1529 , when he seized the ports of Algiers as a base of operations, kidnapping many Christian citizens along the Mediterranean coasts of Spain and Italy. Therefore, in 1535 Charles V undertook a "holy crusade," as it was termed by the emperor, against Barbarossa in Tunis in order to diminish the Otto-

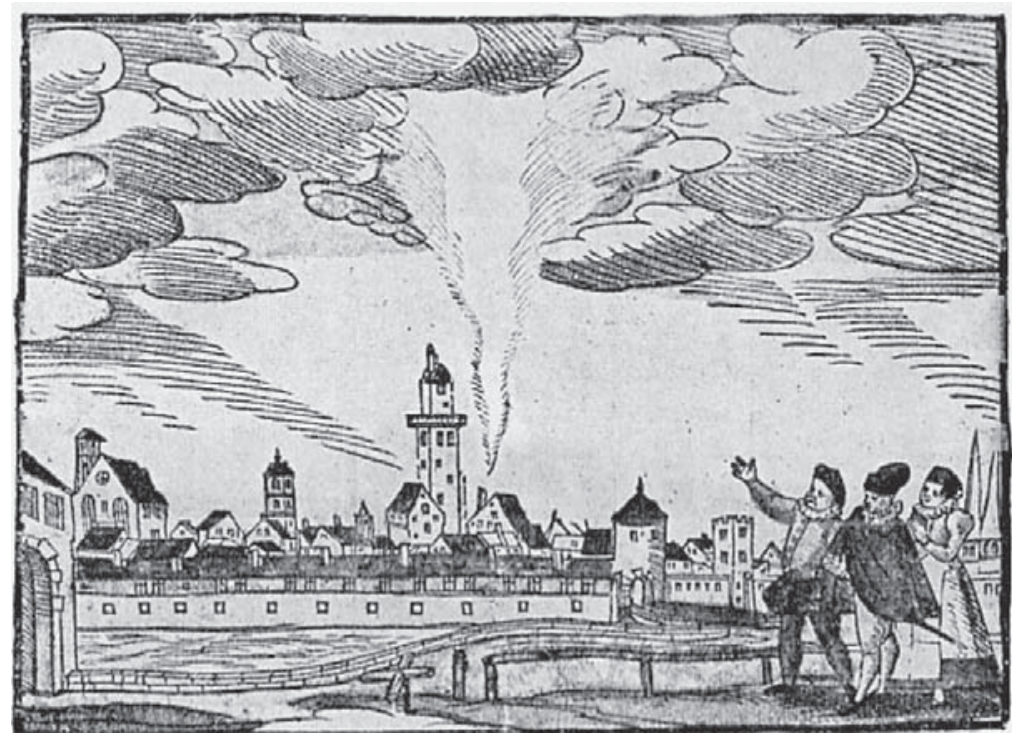

FIG. I. Image of a tornado that was observed and drawn in 1587 (from Wegener 1917). The image caption explains that this tornado was observed in Augsburg, Germany, on 2 Jul 1587, between 12:00 A.M. and I:00 P.M., and was accompanied by heavy weather, hail, thunder, and flashes. The tornado is described as a threatening cloud, formed like a large dragon's tail, moving around for more than half an hour and finally sharpening its lower end. man emperor's power in the western

Mediterranean and to free about 20,000 Christian captives. Shortly after the victory Charles V entered the city of Messina in Sicily, Italy, and was greeted for the first time by a phrase coined by the Roman poet Virgil for the possessions of Augustus Caesar: A solis ortu ad occasum (from the rising to the setting of the sun). As a consequence of the victory in Tunis, the well-known phrase of "an emperor on which the sun never set” was born (Parker 1999).

In spring 1535 the emperor ordered the painter Jan Cornelisz Vermeyen to join the emperor's army in order to work as an artist during the military campaign in Tunis, which began later in the year. The painter made sketches and paintings during this campaign that he used later to produce cartoons ${ }^{2}$ of large size between 1546 and 1550. In 1548 the carpet manufacturer Willem de Pannemaker was entrusted by the emperor's sister Mary with the production of tapestries following these cartoons. In 1554 the series of tapestries "Conquest of Tunis" were successfully finished and were considered to be one of the most important piece of court art of the Habsburgian emperor Charles V. The series is a major monument of military commemorative art that is both more impressive and more inspiring than ingratiating.

\section{THE MAP OF THE MEDITERRANEAN}

BASIN. A tornado above the Iberian Peninsula is the striking feature in the center of the first tapestry of the "Conquest of Tunis" series (Fig. 2). This tapestry, begun in May 1549, was reviewed and approved by the Brussels guild of tapestry weavers in spring 1551. This tapestry, showing the western Mediterranean basin in the form of a portolan ${ }^{3}$ map (Fig. 2), served to introduce pictorially the dramatic history of the Tunis expedition by presenting the related geographic and strategic areas. North Africa is seen at the top of the map and southern Europe at the bottom; Spain is at the lower right, and Italy is at the lower left. The

\footnotetext{
${ }^{2}$ In art history a "cartoon" is a full-sized prepatory sketch for a fresco, tapestry, mosaic, etc.

${ }^{3}$ Portolan maps are nautical atlases originating between the thirteenth and fifteenth centuries. They contain neither latitudes nor longitudes, but lines running along the four axes of the compass. The intersections of these rhumb lines are marked with wind compasses. These maps usually show the Mediterranean Sea. The so-called portolani gives clearly labelled ports, and the related distances between them are quite accurate.
} 


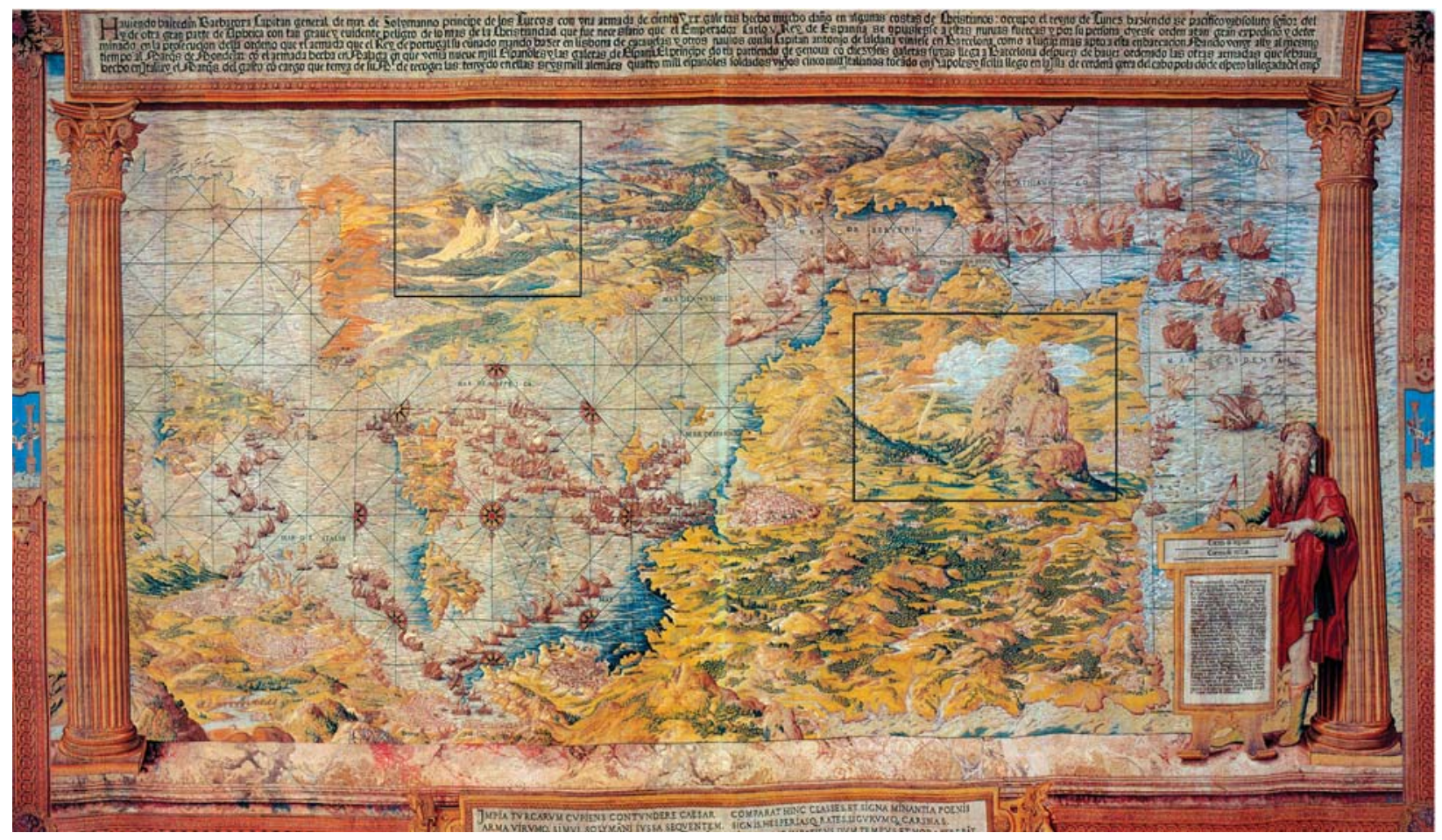

FIG. 2. First tapestry of the "Conquest of Tunis" series woven by the carpet manufacturer Willem de Pannemaker between 1549 and 155I: "The Map of the Mediterranean Basin." The indicated sections are enlarged in Figs. 3 and 4. The caption in Spanish at the top of the tapestry reads (from Horn 1989) "Wishing to overcome the infidel armies of the Turk and the warrior (Barbarossa) who, obeying the orders of Suleiman, raises cruel war against the realms of Spain, Ceasar, Charles the fifth of that name, gathers together with the blessings of Heaven the armies and fleets of Spain and Italy to threaten the African troops. Not blocking delay while time and the hour proceed, he energetically hastens to his ships and his loyal companions" (courtesy of Patrimonio Nacional, Madrid).

north-south orientation, which is the reverse of present-day cartographic practice, was at that time the usual practice for mapping Europe. In addition to Tunis, we also see Naples, Rome, and Genoa, Italy; Marseilles, France; Barcelona, and Malaga, Spain; and Lisbon, Portugal, in a bird's-eye view. Horn (1989) indicated that Vermeyen used this view because he might have seen the famous painting by Albrecht Altdorfer, "The Battle near Issus" (1529), in Munich in 1530, which shows the same perspective (see Gedzelman 1989, Fig. 5).

The person standing on the right of the cartouche is the painter Vermeyen, depicted with a pair of compasses in his hand-the sign of a cosmographer, which was the name given for geographers and cartographers in the sixteenth century (Bernhardus 1693). Vermeyen stated in the cartouche that "Europe and its boundaries, are seen with their chief parts, their broad gulfs, their islands, their winds, at exactly the same distance at which they really lie, the author having taken more care over their precise situation than over the requirements of the painting ... for the countries as well, in strict accordance with cosmography" (taken from Horn 1989).
Most coastlines and locations of the ports are correctly located geographically. But the ports themselves and the ships are overly large in comparison to the rest of the map because Vermeyen deliberatedly sacrificed verisimilitude for clarity. A further schematic modification appears above the Iberian Peninsula. The isolated mountain on the tapestry is Montserrat, which is at a distance of about $50 \mathrm{~km}$ west of Barcelona. This means that the entire Iberian Peninsula, which measures more than $800 \mathrm{~km}$ both in the zonal and meridional direction, is geographically concentrated in the area of Barcelona and its closer environment. The presence of Charles $\mathrm{V}$ in Barcelona and his visit to the Montserrat monastery before the embarkation of the Spanish fleet toward Tunis provide a reason for this concentration. Horn (1989) speculates that Montserrat was rendered so centrally and largely because of its religious significance for the emperor.

\section{WEATHER FEATURES ON THE TAPESTRY.}

Figure 3 depicts an enlarged part of the tapestry that is shown in Fig. 2, where a tornado can be seen close to 
Montserrat leaving a cloud and touching the ground. The cloud resembles a fair-weather cumulus rather than a dark cumulonimbus. The funnel narrows with decreasing height and is very slim where it touches the ground. Clearly, Vermeyen must have seen at least once a funnel cloud, which might have impressed him by its strange and elegant shape. This might have led him to concentrate exclusively on the funnel detail and, therefore, he combined the slender funnel with fair-weather clouds. A further interesting detail appears in Fig. 4, which depicts an area of heavy rain located south of Tunis close to the mountains. A similar scene showing an extended curtain of rain wisps can be found in the background of the fourth tapestry "Skirmishes on the Cape of Carthage" (Fig. 5).

To interpret the weather features that appear one could investigate whether the depicted weather was observed by Vermeyen (and by Charles V) in the corresponding region during the period of the expedition. Contemporary accounts of the expedition to Tunis are plentiful. Virtually every step Charles V ever took drew the attention of the historians of his time, and any major campaign, such as his conquest of Tunis, attracted a whole spate of publications. As a matter of fact, however, a search through literature on Charles V reveals few references to any kind of weather. In the collection of Charles V's letters (Fernández Álvarez 1973) there are various references to weather, for example, "buen tiempo," "fresco," and "faltó de viento," but there is neither a report on a tornado nor heavy rain. The original version of the diary of Charles V, the "memoirs," has been lost, and the only surviving copy is one dated 1620, written in Portuguese. A modern Spanish translation is provided by Cadenas y Vicent (1989) in which there is no mention of special weather related to Charles' crusade, except for a sandstorm occurring close to Tunis and a disastrous storm that occurred during the Algiers campaign (a later expedition to Africa in 1541 in which the emperor lost most of his naval fleet). To sum up, with the exception of the sandstorm, the depicted weather features do not show a documented event, as is the case

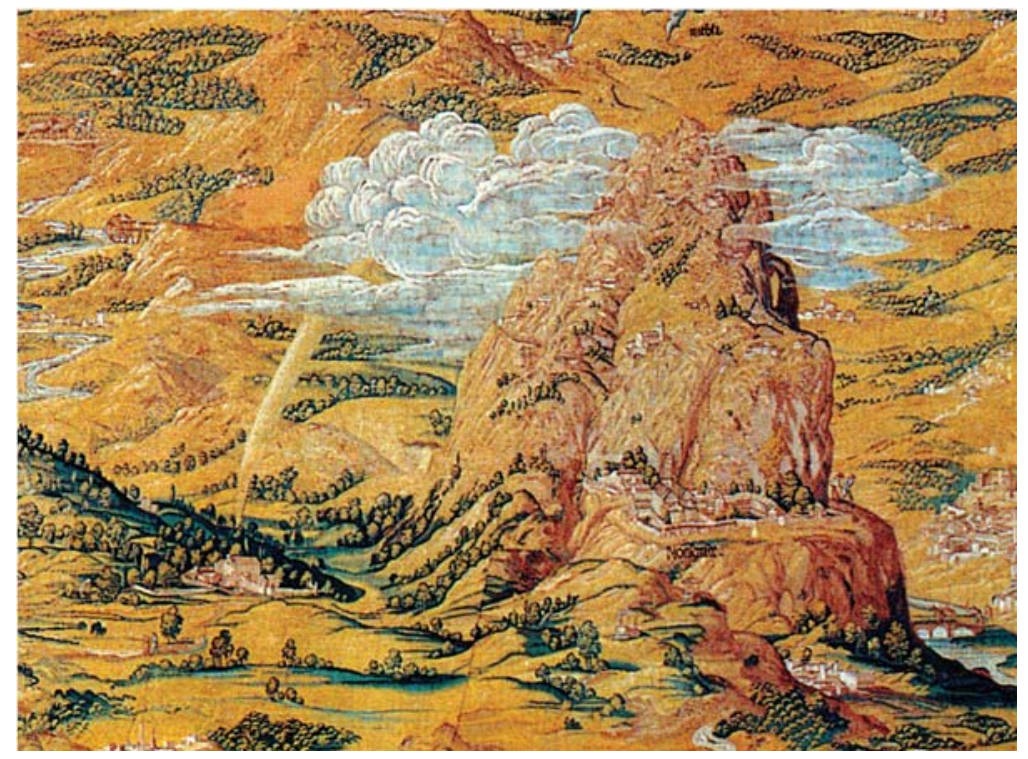

FIG. 3. The tornado near the Monserrat mountain. Enlarged part of Fig. 2 (right-hand-side-indicated section; courtesy of Patrimonio Nacional, Madrid).

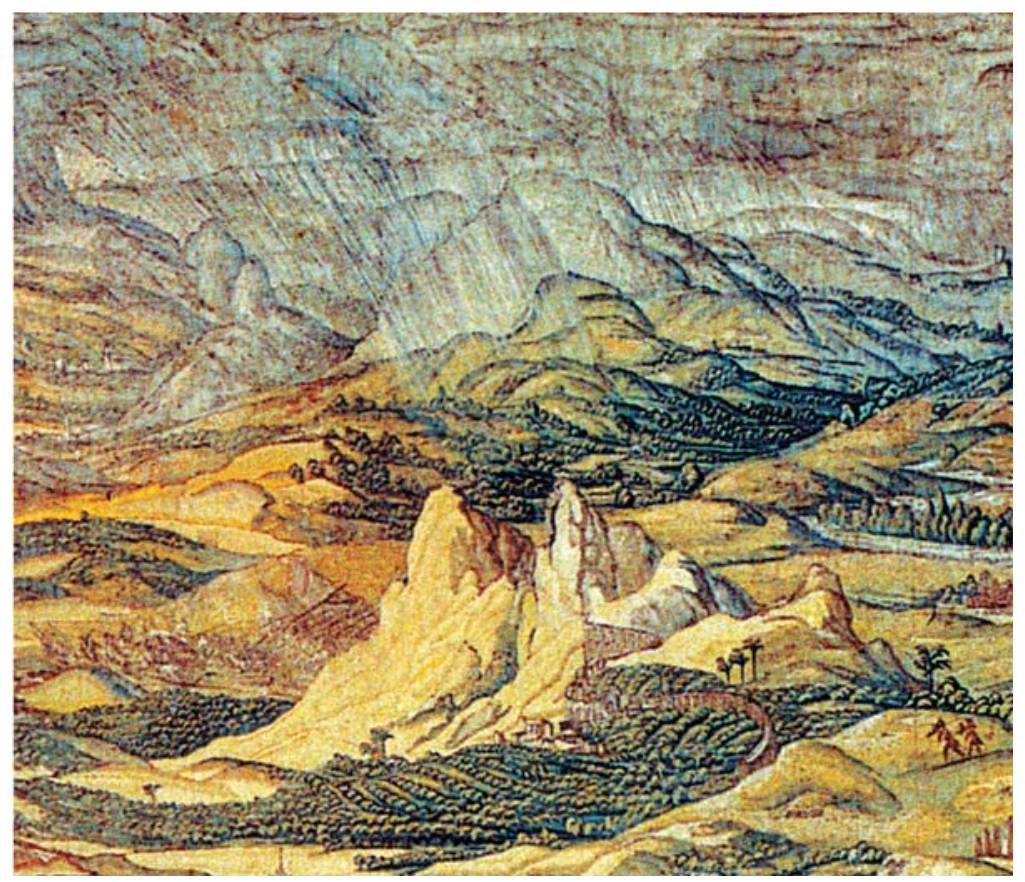

Fig. 4. Heavy rain close to Tunis. Enlarged part of Fig. 2 (left-handside-indicated section; courtesy of Patrimonio Nacional, Madrid).

of the tornado that is observed at a defined place and time given in Fig. 1.

It is likely that weather features were used as decorative or symbolic objects in order to improve the general aesthetic appearance of the piece of art and to support the transmission of religious or political ideas. That the tornado is located so prominently in the tapestry's cen- 


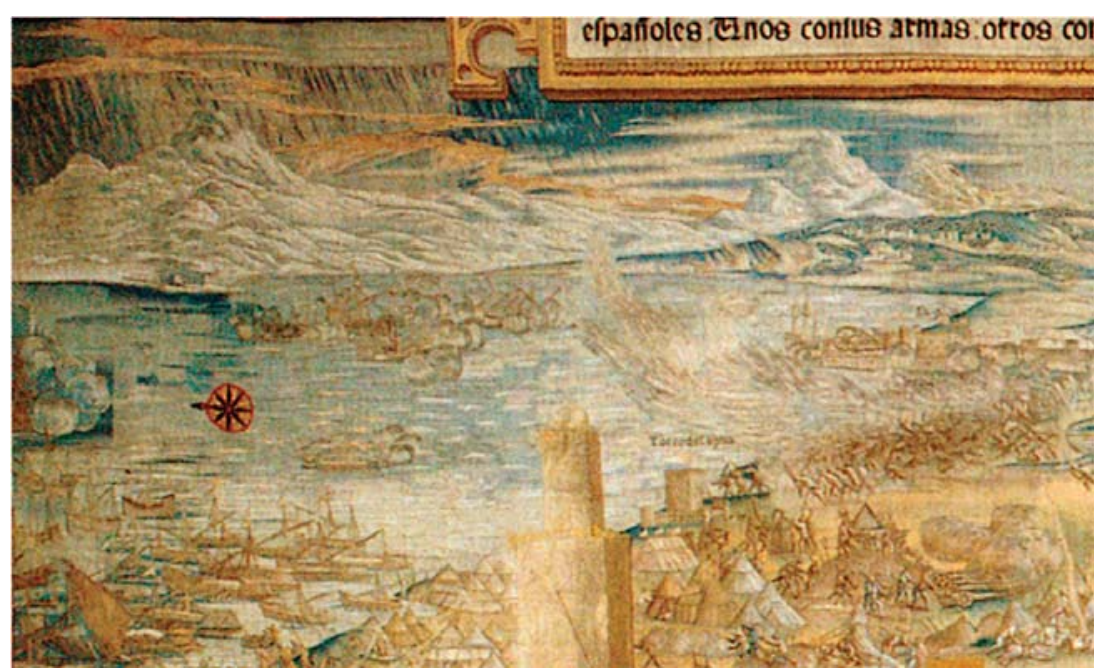

Fig. 5. Detail of the fourth tapestry of the "Conquest of Tunis" series, named "Skirmishes on the Cape of Carthage," depicting curtains of rain wisps close to Tunis and a sandstorm close to port of Goleta. Shown is the top-left part of the tapestry (courtesy of Patrimonio Nacional, Madrid). difficulty of precisely locating these features within the Iberian Peninsula, the artist might have exercised artistic licence in locating Montserrat, Molins de Rei, Tibidabo, and Barcelona in relation to each other.

In 1535 Charles $\mathrm{V}$ traveled from Madrid (2 March) to Barcelona (3 April) via Saragossa (Fernández Álvarez 1999); the emperor stayed in Molins de Rei for two days (Foronda y Aguilera 1914), where he probably was lodged by the village's baroness, Estefania de Requesens, wife of his councillor, Juan de Zuñiga. Before arriving in Molins de Rei, the emperor visited the Montser- ter and is so dominant in structure that the eye is drawn to it perhaps emphasizes its symbolic texture. Thornes (2000) pointed out that weather features, such as clouds, are not just decorative objects but "constituted one of the elements of pictorial semiotics, a graph whose functions varied over time." It is a known fact that the transformation of pictorial weather features in art from religious symbols to natural phenomena started in the Renaissance period. Thus, one should also investigate if the weather features are used emblematically, which means that an abstract idea is expressed metaphorically. Emblemata played an important role in all types of European art between the sixteenth and eighteenth centuries. Pictorial elements, such as weather, clouds, and even landscapes, were used to signify philosophical and political ideas expressed in paintings, tapestries, and other pieces of art.

The symbolic interpretation suggests that clouds can be considered as a celestial condition, for example, when a divine hand appears from a cloud, which is a picture frequently used during the Renaissance period. Similar to a divine hand, the tornado beneath the cloud points downward like a finger to an ensemble of houses close to Montserrat. Behind and toward the left of this village a ridge can be seen that rises toward the left (Fig. 3) and ends finally in a small hill (Fig. 2). Comparison with a modern map suggests that the hill depicts Tibidabo Mountain (512 $\mathrm{m})$, located to the west of Barcelona, and that the village might be the present-day village of Molins de Rei. Because of the exaggerated scale and the rat monastery on 31 March. Two months later, in May 1535, Charles V went again on a pilgrimage to Montserrat seeking divine support for his crusade against the Muslim admiral Barbarossa. After this visit Charles $\mathrm{V}$ returned on the same day to Barcelona to prepare for the fleet's immanent departure (Prudencio de Sandoval 1955).

It is not clear if the fingerlike tornado was drawn simply to emphasize the Montserrat area or if it is pointing to the small village of Molins de Rei. Nevertheless, it is convincing that the tornado expresses emblematically God's blessing the crusade against Islam. This is in agreement with Cooper (1978), who pointed out that whirlwinds and tornadoes were regarded as a manifestation of energy in nature, rising or descending from a center of power associated with God. The funnel, thus, becomes a vehicle for divinity. Similarly, Cirlot (1988) corroborates this because symbolically "everything that occurs in heaven or descends therefrom, has a sacred quality about it."

Another interesting meteorological detail-a curtain of rain wisps to the south of Tunis-is not easy to distinguish, even to a person standing in front of the tapestry. The oblique stroke pattern in blue tint apparently represents slantwise falling water. This storm, with heavy rain, seems to point emblematically to the battle that occurred within this area at the end of the crusade. The heavy rain appearing in this tapestry could be interpreted as a harbinger of the upcoming event, which is then redundantly shown in the background of the fourth tapestry, 
depicting details of the battle close to Tunis (Fig. 5). Thus, it is conceivable that the storm with heavy rain is interpreted as a manifestation of divine anger and punishment of the Muslim corsair Barbarossa. On the other hand, the rainstorm could also indicate God's blessing and approval of the troops who needed rain. Many rains after battles are symbolically considered a "cleansing." The question is whether it is a sign of divine approval, or a trial to be endured heroically.

The imperial troops, having conquered the port of Goletta, suffered deeply from the unendurable heat and the lack of fresh water. The emperor wrote to his sister Mary that "we died for thirst and heat" (Brandi 1937). At the same time, a violent sandstorm hampered the troops in their attack on Tunis. In the top caption of the fourth tapestry this storm is dramatically described as follows: "our men are blinded by the thick dust ... thus fighting as much with dust as with arms." Horn (1989) pointed out that this sandstorm is depicted on the fourth tapestry, where Muslims attack the trenches under cover of a blinding sandstorm (Fig. 5). Its depiction is merely the narrative of the observed situation.

In summary, the tornado appears at a location that marks the beginning of the Tunis expedition-the holy Montserrat mountain near Barcelona-whereas the heavy rain appears at the end of the crusade-in Tunis. The caption of the first tapestry states that Charles V led an international crusade against the enemies of Christendom. This message is made particularly clear in the second tapestry, in which Christ is introduced as the true commander of the expedition (Horn 1989). It is clear from the composition of the tornado and heavy rain that they were designed as symmetrical counterparts, symbolizing the beginning and end of the crusade.

Clearly, these are all speculations and have to be taken with caution because our contemporary view in interpreting and understanding those symbols is limited, and we usually underestimate their importance. On the other hand, one has to keep in mind that during the Renaissance era, the use of symbols, emblems, and allegories in art was widespread, and emblematic language was very well understood. The painting "The Tempest" of the Italian artist Giorgione provides a well-known example of the difficult task of interpreting symbols in art showing the importance of the symbolic language that is a mixture of naturalism and narrative. His naturalistic depiction of lightning is embedded in a composition that defies definitive interpretation. The painting has been variously interpreted as mythological, religious, an allegory of virtues, and a free poetic invention. More than twenty different symbolic interpretations have been proposed since the painting was created, around 1509 (Settis 1982).

\section{TECHNICAL REMARKS ON THE TAP.}

ESTRIES. During the first half of the sixteenth century, tapestries were the obligatory fixture of a European court and were used as an instrument for political propaganda and dynastic demonstration. The tapestries of the "Conquest of Tunis" series are large, with a mean height of about $4 \mathrm{~m}$ and a width of 7-12 m. Few rooms would have been large enough to allow for the entire series to hang at once because it covered a wall of more than a 100 -m length. In combination, the 12 huge tapestries displayed in one vast and rich chamber must have looked grandiose, almost overwhelming. Therefore, they were used to decorate festivity halls for longer periods of times. Normally, such huge tapestries were hung on the outside walls of buildings. The first prominent opportunity to show the series was the marriage of Philippe II-the emperor's son-to the Queen Mary Tudor in Winchester Cathedral on 25 July 1554. The tapestries accompanied the emperor in all of his travels throughout Europe, and when he retired in Yuste, he brought the tapestries with him. Ever since, they have remained in Spain.

For a constantly traveling emperor, such as Charles $\mathrm{V}$, these tapestries were favorable because they were easier to transport than paintings of a similar size. Another reason was the very striking aesthetic effect of tapestries. A further advantage of the tapestries was the possibility of reproducing them mechanically; thus, the same depiction (and propaganda) could be presented simultaneously in different places.

Taking into account the significant expense and the great effort that were required to move these tapestries, one can surmise the extent of importance that was ascribed to them. Also, the production costs of the prepatory cartoons and the series of tapestries were enormous, around 33,000 Flemish pounds. This amounts to about 160,000 Gulden, or about 9,000,000 pounds Sterling in 1903 (Van Ysselsteyn 1969). Taking into account the development of prices of wheat, cost of living, and wholesale prices since 1903 (Jacobs 1964, Mitchell 1998), the tapestries are valued in today's currency at 30-40 million Euro. When one considers that Charles V raised the necessary funds while he continually hovered on the verge of bankruptcy, there can remain no doubt that the "Conquest of Tunis" was of immense importance to him. It was his ambition to be recognized as the leader of Christendom, and he viewed his Tunis expedition as a demonstration of his role in history. 
The original series consisted of 12 cartoons and tapestries; today, 10 of each still exist. The first scene of the "Conquest of Tunis" series has survived only in tapestry form. The cartoons are stored in the Vienna Museum of Art History (Kunsthistorisches Museum). The tapestries can be found in the Palacio Real in Madrid, and an inferior replica is exhibited in the Ral Alcázar of Seville. Another series of tapestries using the painted prototypes of Vermeyen was done during the years 1712-21 by Jodocus de Vos in Brussels. These are stored today in the Vienna Museum of Art History. Images of the original series of tapestries are reproduced in Seipel (2000).

SUMMARY AND DISCUSSION. In the present paper we have shown a Renaissance depiction of a tornado, which is, to the authors' knowledge, the earliest depiction thereof worldwide, at least in the Latin West. East Indian and Chinese art may contain depictions of tornadoes long before the sixteenth century. The tornado appears on the first tapestry of the "Conquest of Tunis" series that was woven between 1549 and 1551; the same tapestry also shows a heavy rain shower. Furthermore, a similar heavy rain shower and a sandstorm are depicted in the fourth tapestry of the series. The original model for these tapestries, painted by Vermeyen, was finished several years earlier. The artistic depiction of the tornado is a highly unique feature, considering the contemporary variety of meteorological phenomena appearing in tapestries and wall paintings of the Italian High Renaissance between 1510 and 1600 .

A literature search indicates that the depicted weather phenomena, except the sandstorm, were not recorded during the crusade to Tunis. The tornado and the heavy rain seem to be implemented in order to emphasize symbolically the beginning and ending of the "holy crusade." The tornado that appears close to the Montserrat mountain indicates God's blessing of the expedition, which began in Barcelona. The final battle occurred in Tunis where a storm with heavy rain appears on the tapestry. The symbolic interpretation of the storm is that it should be seen as a manifestation of divine anger and punishment of the Muslim corsair Barbarossa. On the other hand, the rain storm could also indicate God's blessing and approval of the troops who needed rain. Arguments can be made to support both interpretations, and it is not clear that one needs a definitive answer either way, as long as one knows that it has some deeper meaning.

The details of the tapestry show that the depiction of nature is complicated in the paintings, as well as in other pieces of art of the sixteenth century, because it combines naturalistic parts or details in an unrealistic manner. These details could be of a narrative, emblematic, and even schematic character. It can be concluded that in very few cases the paintings are an exact documentation of nature, but, they are, in general, a balanced representation between the description of facts on the one hand and free intervention on the other. The artist acted as the creator of plausible fictions. The question of fiction, invention of nature, and nature in pieces of art has to be answered with the following paradox: the artists invented their art naturalistically. At that time the artist's aim was to use the characteristic elements of the landscape, including weather features, and to link them to symbolic ideas. On the other hand, the depiction of landscapes and weather for its own sake started at the same time (see, e.g., the sketches of Albrecht Dürer). But it was not until the seventeenth century that painting the sky and landscapes became fashionable. With regard to art history there is a shift from the textual narrative representation in Renaissance Italy, to the visual descriptive depiction in Dutch seventeenth-century painting between the early and late Renaissance period. The painter Vermeyen, with his cartoons of the "Conquest of Tunis" series stands in a very interesting juncture in art history-somewhat between these two chronologically, geographically, and in the form of representation.

Horn (1989) pointed out that the "Conquest of Tunis" series gives a reliable and complete account of the campaign and represents official history, narrated in the captions and depictions of the tapestries. One must not look to them, or the other written accounts of the expedition, for modern, critical history writing, but for an official version of what happened, along with emblematic puzzles. White (1947) pointed out that the later Roman Empire and early Middle Ages lived not "in a world of visible facts but rather in a world of symbols." Thus, the knowledge of the cultural context is a necessary precondition for the interpretation and understanding of contemporary art and science, for example, the tapestries' emblematic puzzles.

The "emblematic world view" (Ashworth 1990) is one important factor in determining Renaissance attitudes toward the natural world. The essence of this view is the belief that everything in the cosmos has myriad hidden meanings. The notion that nature should be studied in isolation from the rest of the universe, and that inquiry should be limited to its physical description, was a notion that was completely alien to Renaissance thought. The effect 
upon science of such a view of nature was, of course, disastrous. However, the rise of naturalism in art as part of a larger movement also brought about modern science. Modern science, as it first appeared in the later Middle Ages, was one result of a shift in the general attitude toward nature - the change from a symbolic, subjective to a naturalistic, objective view of the physical environment. It was recognized that nature is interesting and important in and of itself. The tornado and the heavy rain as depicted in the tapestries demonstrate on the one hand the temporary emblematic view by their narrative texture, and on the other hand give evidence for the artist's attitude to observe nature precisely by the perfect naturalistic depiction of the atmospheric phenomena.

ACKNOWLEDGMENTS. We gratefully acknowledge support in finding adequate literature from Anita Tafferner (München), Helga Rosenberger (Universitätsbibliothek, München), Nikolai Dotzek (DLR, Oberpfaffenhofen), Guiseppe Frustaci (Italian Meteorological Service, Rome), and Andrea Buzzi (ISAC-CNR, Bologna). Klaus Bodendieck (München) and Gabriele Koopschmidt (Universität München) gave valuable hints for art-related topics. Lourdes de Louis (Patrimonio Nacional, Madrid) helped to find out deficiencies of the tapestries. The authors are pleased to put on record their indebtedness to James R. Fleming (Colby College, Waterville), for his helpful comments and repeated assistance. The comments of Hans Volkert (DLR) and of three referees are gratefully acknowledged.

\section{REFERENCES}

Ashworth, W. B., 1990: Natural history and the emblematic world view. Reappraisals of the Scientific Revolution, D. C. Lindberg and R. S. Westman, Eds., Cambridge University Press, 303-332.

Bernhardus, V., 1693: Cosmography and Geography. Blome.

Brandi, K., 1937: Kaiser Karl V (Emperor Charles V). Bruckmann Verlag München, 571 pp.

Brooks, C. F., 1941: Two winter storms encountered by Columbus in 1493 near the Azores. Bull. Amer. Meteor. Soc., 22, 303-309.

Cadenas y Vicent, de V., 1989: Las Supuestas "Memorias" del Emperador Carlos V (The Presumed "Memoirs" of the Emperor Charles V). Hidalguia, 373 pp.

Cirlot, J.-E., 1988: A Dictionary of Symbols. Routledge and Kegan Paul, 419 pp.

Cooper, J. C., 1978: An Illustrated Encyclopaedia of Traditional Symbols. Thames and Hudson, 208 pp.

Fernández Álvarez, M., 1973: Corpus Documental de Carlos V: I (1516-1539). Fundación Juan March,
Consejo Superior de Investigaciones Cientificas, Salamanca, 562 pp.

- 1999: Carlos V. el César y el Hombre (Charles V, the Emperor and the Man). Editional Espasa Calpe, S.A., 887 pp.

Fleming, J. R., 1990: Meteorology in America, 1800-1870.

The John Hopkins University Press, 264 pp.

— raphy of Meteorology: From the Beginning of Printing to 1889. Diane Publishing, 704 pp.

Foronda y Aguilera, M., 1914: Estancias y Viajes del Emperador Carlos V (Sojourns and Journeys of the Emperor Charles V). Sucesores de Rivadeneyral, 714 pp.

Gedzelman, S. D., 1989: Cloud classification before Luke Howard. Bull. Amer. Meteor. Soc., 70, 303-309.

Hellmann, G., 1901: Meteorologische Beobachtungen vom XIV. Bis XVII. Jahrhundert (Meteorological Observations between the XIV and XVII Century). Neudrucke von Schriften und Karten über Meteorologie und Erdmagnetismus, G. Hellmann, Ed., No. 13, Verlag, 127 pp.

—, 1908: The dawn of meteorology. Quart. J. Roy.

Meteor. Soc., 34, 221-232.

—, 1915: Beiträge zur Geschichte der Meteorologie (Contributions to the History of Meteorology). Veröffentlichungen des Koniglich Preußischen Meteorologischen Instituts, No. 273, 131 pp.

__, 1924a: Versuch einer Geschichte der Wettervorhersage in XVI. Jahrhundert (An Attempt of the History of Weather Forecasting History during the XVI Century). Abhandlungen. der Preussischen Akademie der Wissenschaften, PhysikalischMathematische Klasse, No. 1, 26 pp.

_- 1924b: Wasserhosen auf dem atlantischen Ozean (Waterspout in the Atlantic Ocean). Sitzungsberichte der Preussischen Akademie der Wissenschaften, Mitteilung aus der Sitzung der PhysikalischMathematische Klasse vom 12, November 1925, 539-544.

Heninger, S. K., 1960: A Handbook of Renaissance Meteorology: With Particular Reference to Elizabethan and Jacobean Literature. Duke University Press, 269 pp.

Horn, H. J., 1989: Jan Cornelisz Vermeyen. Davaco, 504 pp.

Jacobs, A., 1964: Preis I: Preisgeschichte (Costs I: History of costs). Handwörterbuch der Sozialwissenschaften, VIII, In Beckerath, et al., Eds, Gustav Fischer Verlag, 459-476.

Kentworthy, J. M., 2000: The use of the word "tornado" in West Africa and the eastern tropical Atlantic. Weather, 55, 60-62. 
Ludlum, D. M., 1963: Early American Hurricanes, 1492-1870. Amer. Meteor. Soc., 198 pp.

_ 1970: Early American Tornadoes, 1586-1870. Amer. Meteor. Soc., 219 pp.

Machiavelli, N., 1532: The Severe Storm of August 24, 1456 in Italy. Book VI/34, Istorie fiorentine (1988: Florentine Histories), Translated by L. F. Banfield, Princeton University Press, 391 pp.

Mitchell, B. R., 1998: International Historical Statistics. Europe 1750-1993. Macmillan Reference LTD, $960 \mathrm{pp}$.

Oxford English Dictionary, 1989: Clendon Press, 22000 pp.

Parker, G., 1999: Prologue. Carolus V Imperator, P. N. Palacio, Ed., Lunwerg, 5-7.

Prudencio de Sandoval, F., 1955: Historia de la Vida y Hechos del Emperador Carlos V (History of Life and Acts of the Emperor Charles V). Vol. 79-82, In Seco Serrano, Ed., Biblioteca de Autores Españoles

Seipel, W., 2000: Der Kriegszug Kaiser Karl V gegen Tunis: Kartons und Tapisserien (The Crusade of the Emperor Charles V against Tunis: Cartoons and Tapestries). Kunsthistorisches Museum Wien, $139 \mathrm{pp}$.

Settis, S., 1982: Giorgiones "Gewitter": Auftraggeber und verborgenes Sujet eines Bildes in der Renaissance (Giorgiones "The Tempest”). Wagenbach Verlag, $208 \mathrm{pp}$.

Snow, J. T., and A. L. Wyatt, 1997: Back to basics: The tornado, nature's most violent wind: Part I-worldwide occurrence and categorisation. Weather, 52, 298-304.

Thornes, J. E., 2000: A brief history of weather in European landscape art. Weather, 55, 363-375.

Van Ysselsteyn, G. T., 1969: Tapestry, the Most Expensive Industry of the XVth and XVIth Centuries. Van Goor Zonen, 232 pp.

Wegener, A., 1917: Wind- und Wasserhosen in Europa (Tornadoes and Waterspouts in Europe). Vieweg und Sohn Verlag, 301 pp.

White, L., Jr., 1947: Natural science and naturalistic art in the Middle Ages. Amer. Historical Rev., 52, 421-435. 